\title{
PENGARUH PROFITABILITAS, INVESTMENT OPPORTUNITY SET (IOS), LIKUIDITAS DAN KEBIJAKAN DIVIDEN (Studi pada Perusahaan Sektor Consumer Goods di Bursa Efek Indonesia)
}

\author{
Hesty Erviani Zulaecha', Desrir Miftah'2 \\ Universitas Muhammadiyah Tangerang, 2Universitas Islam Negeri Syarif Kasim Riau \\ 'hesty.erviani@umt.ac.id, 2desrir.miftah@uin-suska.ac.id
}

Current Ratio.

\begin{tabular}{l}
\hline Keyword \\
\hline Dividen Payout Ratio, Return \\
On Assets, Sales Growth, \\
Market to Book Value, \\
Current Ratio.
\end{tabular}

\section{Abstract}

The purpose of investment done by investors in the capital market is to get return of said investment. Expectations of investors in investing is to obtain dividend payout ratio. dividend payout ratio can be determined by analyzing the company's financial performance which is proxied by Return on Assets, Sales Growth, Market to Book Value and Current Ratio. Companies classified in consumer goods sector selected as the population used in this study are listed on the Stock Exchange 2013-2016 period. Purposive sampling is used to get the sample in this research using criterias and 12 companies or 48 firm-years are the samples. This research is using multiple linear regression. Based on the results of the partial test (t test) on the real level $(\alpha)=5 \%$ can be seen that the variablel return on assets have a significant and positive impact on dividen payout ratio, Sales Growth, Market to Book Value and Current Ratio have no significant effect on dividen payout ratio.

\section{PENDAHULUAN}

\section{Latar Belakang Masalah}

Kebijakan dividen (dividend policy) adalah keputusan pihak manajemen untuk menentukan perlakuan terhadap earning after tax (EAT), apakah dibagikan sebagai dividen, diinvestasikan kembali, atau sebagian dibagikan sebagai dividen, sebagian lagi diinvestasikan kembali ke perusahaan. Persentase dividen yang dibagi dari EAT itu disebut dividend payout ratio(Sugiarso dan Winarni, 2005). Kebijakan dividen yang optimal adalah kebijakan dividen yang bisa menciptakan keseimbangan di antara dividen saat ini dan pertumbuhan di masa mendatang yang bisa memaksimumkan harga saham perusahaan (Darminto, 2008).

Salah satu emiten yang tak pernah membagikan dividen adalah PT Hero Supermarket Tbk (HERO). Emiten ini beralasan, membutuhkan dana ekspansi. HERO pun belum akan membagi dividen untuk hasil laba bersih di tahun 20I2. Padahal laba bersih HERO selalu bertumbuh. Bahkan per kuartal III 2012, laba bersih HERO mencapai Rp 222,02 miliar, naik $18,04 \%$ year on year (www.mappijatim.or.id). Dengan demikian, masalah keputusan pembagian dividen merupakan suatu masalah yang paling sering dihadapi perusahaan. Hal inilah yang menyebabkan kebijakan dividen sampai saat ini terus menjadi perdebatan terutama pada saat penetapan kebijakan dividen.

Faktor- faktor yang diduga mempengaruhi kebijakan dividen dan yang menjadi fokus perhatian penelitian ini adalah profitabilitas, set kesempatan investasi dan likuiditas. Profitabilitas merupakan kemampuan perusahaan dalam mencari keuntungan atau laba dalam suatu periode tersebut, sehingga mempunyai pengaruh terhadap kebijakan dividen. Set kesempatan investasi atau investment opportunity set (IOS) yang diproksi dengan tingkat pertumbuhan penjualan (sales growth) dan rasio harga pasar terhadap nilai buku (Market to Book Value). Semakin tinggi tingkat pertumbuhan perusahaan, maka akan meningkat kebutuhan perusahaan untuk membiayai ekspansinya. Likuiditas adalah kemampuan perusahaan dalam memenuhi kewajiban jangka pendeknya tepat pada waktunya. Hal ini dikarenakan, untuk membayar dividen diperlukan ketersediaan dana dalam hal ini adalah kas yang dimiliki oleh perusahaan. Perusahaan yang mempunyai laba yang tinggi belum tentu dapat membayarkan dividen kepada para pemegang saham karena tidak adanya dana untuk membayar dividen (Darminto, 2008). 
Penelitian terdahulu yang dilakukan oleh Suharli (2007), Arilaha (2009), Marpaung dan Hadianto (2009), dan Musthikawati (2010) profitabilitas berpengaruh positif terhadap kebijakan dividen. Tetapi menurut Kania Bacon (2005) dan Dewi (2008) menyatakan bahwa profitabilitas berpengaruh negatif terhadap kebijakan dividen. Sedangkan penelitian yang dilakukan Deitiana (2009) dan Islamiyah (20/2) menyatakan bahwa profitabilitas tidak memiliki pengaruh yang signifikan terhadap kebijakan dividen.

Penelitian yang dilakukan oleh Marpaung dan Hadianto (2009), Gill, et all (2010) dan Musthikawati (2010) menunjukkan bahwa IOS yang diproksikan oleh Sales Growth tidak berpengaruh signifikan terhadap kebijakan dividen. Tetapi penelitian Marpaung dan Hadianto (2009), tentang IOS yang diproksikan oleh Market to Book Value (MTBV) berpengaruh positif terhadap kebijakan dividen. Penelitian Musthikawati (2010) mengatakan bahwa MTBV memiliki pengaruh negatif terhadap kebijakan dividen.

Penelitian tentang Likuiditas dengan kebijakan dividen dilakukan Kania Bacon (2005) dan Arilaha (2009) menemukan bukti bahwa likuiditas yang diproksikan oleh Current Ratio tidak berpengaruh terhadap kebijakan dividen.

Dari hasil penelitian terdahulu masih terdapatnya perbedaan hasil penelitian, maka penulis tertarik untuk melakukan penelitian kembali tentang kebijakan dividen dengan judul pengaruh profitabilitas, investment opportunity set (IOS), likuiditas terhadap kebijakan dividen.

\section{Rumusan Masalah}

Rumusan masalah dalam penelitian ini :

I. Apakah Profitabilitas berpengaruh terhadap kebijakan dividen?

2. Apakah Investment Opportunity Set(IOS) berpengaruh terhadap kebijakan dividen?

3. Apakah Likuiditas berpengaruh terhadap kebijakan dividen?

\section{Tujuan Penelitian}

Adapun tujuan penelitian ini adalah untuk menganalisis dan memperoleh bukti empiris mengenai :

I. Pengaruh Profitabilitas terhadap kebijakan dividen?

2. Pengaruhlnvestment Opportunity Set (IOS) terhadap kebijakan dividen?

3. Pengaruh Likuiditas terhadap kebijakan dividen?

\section{TINJAUAN PUSTAKA}

\section{Signalling Theory}

Isyarat atau signal menurut (Brigham dan Weston, 1990) adalah suatu tindakan yang diambil manajemen perusahaan yang memberi petunjuk bagi investor tentang bagaimana manajemen memandang prospek perusahaan. Signaling theory menjelaskan bahwa informasi yang dikeluarkan oleh perusahaan termasuk cash dividend yang dibayarkan dianggap investor sebagai sinyal prospek perusahaan di masa mendatang (Aji, 20I2).

Dividend signaling theory pertama kali dicetuskan oleh Bhattacharya (1979). Dividend signaling theory mendasari dugaan bahwa pengumuman dividen mempunyai kandungan informasi yang mengakibatkan adanya reaksi saham (Embara, 20I2). Sedangkan menurut Modigliani dan Miller (196I) atau yang lebih dikenal dengan sebutan MM berpendapat bahwa suatu kenaikan dividen yang di atas kenaikan normal biasanya merupakan suatu sinyal kepada para investor bahwa manajemen perusahaan meramalkan suatu penghasilan yang baik di masa yang akan datang. Sebaliknya, suatu penurunan atau kenaikan dividen yang dibawah kenaikan normal diyakini investor sebagai suatu sinyal bahwa perusahaan menghadapi masa sulit di masa mendatang.

\section{Teori Kebijakan Dividen}

Menurut Baker (2009) dalam Nugroho, (20II) menyebutkan ada tiga teori yang muncul akibat adanya dividen yaitu:

I) Bird in the hand theory

Sependapat dengan Gordon dan Lintner yang menyatakan bahwa biaya modal sendiri akan naik jika Devidend Payout Ratio (DPR) rendah. Hal ini dikarenakan investor lebih suka menerima dividen daripada capital gain.

2) Tax preference theory

Merupakan suatu teori yang menyatakan bahwa karena adanya pajak terhadap keuntungan dividen maka jika pajak yang dikenakan tinggi, para investor lebih menyukai Dividen karena dapat menunda pembayaran pajak.

3) Information content or signaling hypothesis Pada teori ini Modigliani dan Miller (196I) berpendapat bahwa suatu kenaikan dividen yang diatas kenaikan normal biasanya merupakan suatu sinyal kepada para investor bahwa manajemen perusahaan meramalkan suatu penghasilan yang baik dimasa yang akan datang. Sebaliknya, suatu penurunan atau kenaikan dividen yang dibawah kenaikan normal diyakini investor 
sebagai suatu sinyal bahwa perusahaan menghadapi masa sulit di masa mendatang.

\section{Kebijakan Dividen}

Kebijakan dividen merupakan keputusan apakah laba yang diperoleh perusahaan akan dibagikan kepada pemegang saham sebagai dividen atau akan ditahan guna pembiayaan investasi di masa yang akan datang (Dewi, S.C, 2008). Dividen menurut Baridwan (1990), adalah pembagian laba perusahaan kepada para pemegang saham yang besarnya sebanding dengan jumlah lembar saham yang dimiliki. Biasanya dividen dibagikan dengan interval waktu yang tetap, tetapi kadang-kadang diadakan pembagian dividen pada waktu yang tidak biasa (Hardiatmo, 2012). Laba ditahan merupakan salah satu sumber dana yang paling penting untuk membiayai pertumbuhan perusahaan, sedangkan dividen merupakan aliran kas yang dibayar kepada para pemegang saham (Riyanto, 200 I dalam Latiefasari, 20I I).

Kebijakan dividen diukur dengan rasio pembayaran deviden (dividend payout ratio) yaitu perbandingan antara Dividend Per Share (DPS) dengan Earning Per Share (EPS). Keputusan mengenai jumlah laba yang ditahan dan dividen yang dibagikan diputuskan dalam Rapat Umum Pemegang Saham (RUPS) (Robert, 1997).

\section{Profitabilitas}

Menurut Kasmir (2016), profitabilitas adalah kemampuan perusahaan untuk menghasilkan laba pada periode tertentu. Laba inilah yang akan menjadi dasar pembagian dividen perusahaan, apakah dividen tunai ataupun dividen saham. Laba yang dihasilkan dari penjualan dan pendapatan investasinya. Peningkatan laba bersih perusahaan akan meningkatkan tingkat pengembalian investasi berupa pendapatan dividen bagi investor.

$$
\text { Profitabilitas dapat diukur }
$$

menggunakanbeberapaindikator seperti profit margin on sales, return on investment (ROI), return on equity (ROE) dan laba per lembar saham. Untuk mengukur profitabilitas menggunakan hasil pengembalian investasi atau lebih dikenal ROI atau return on assets (ROA) merupakan rasio yang menunjukkan hasil (return) atas jumlah aktiva yang digunakan dalam perusahaan. Return on investment juga merupakan suatu ukuran tentang efektifitas manajemen dalam mengelola investasinya (Kasmir, 2016).

Menurut Sartono (2001:122) dalam Musthikawati (2010), kondisi profitabilitas baik akan mendorong para investor untuk melakukan investasi pada perusahaan tersebut. Dengan demikian bagi investor jangka panjang akan sangat berkepentingan dengan análisis profitabilitas ini, misalnya bagi pemegang saham akan melihat keuntungan yang benar-benar akan di terima dalam bentuk dividen Rasio profitabilitas menunjukkan perusahaan yang memiliki stabilitas keuntungan dapat menetapkan tingkat pembayaran dividen dan mensinyalkan kualitas atas laba mereka. Oleh karena itu, semakin tinggi rasio profitabilitas maka semakin besar dividen yang dibagikan kepada investor (Arilaha, 2009).

\section{Set Kesempatan Investasi atau Investment Opportunity Set (IOS)}

Menurut Smith dan Watts (1992), investment opportunity set (IOS) merupakan hasil dari pilihan-pilihan untuk membuat investasi di masa mendatang. Set kesempatan investasi menunjukkan kemampuan perusahaan memperoleh keuntungan dari prospek pertumbuhan. Prospek perusahaan yang tumbuh bagi investor merupakan suatu hal yang menguntungkan, karena investasi yang ditanamkan diharapkan akan memberikan return yang tinggi (Dadri, 20l I).

Menurut penelitian D'Souza dan Saxena (1999) dan Anil Kapoor (2008) dalam Marpaung (2009) Investment Opportunity Set (IOS) atau Set Kesempatan Investasi dalam penelitian ini diproksi dengan dua variabel yaitu :

a. Sales Growth atau Pertumbuhan Penjualan

Pertumbuhan Penjualan mencerminkan manifestasi keberhasilan investasi periode masa lalu dan dijadikan sebagai prediksi pertumbuhan masa yang akan datang. Laju pertumbuhan suatu perusahaan akan mempengaruhi kemampuan mempertahankan keuntungan dalam menandai kesempatandi masa mendatang (Barton et al, 1989). Pertumbuhan penjualan tinggi, maka akan mencerminkan pendapatan meningkat sehingga pembayaran dividen cenderung meningkat (Deitiana, 20I I).

Sales growth dapat dilihat dari perubahan total penjualan tahun $\mathrm{t}$ ke tahun t-I dan kemudian dibagi dengan penjualan ke tahun $\mathrm{t}-\mathrm{I}$. Bagi perusahaan dengan tingkat pertumbuhan penjualan dan laba yang tinggi kecenderungan perusahaan membagikan dividen lebih konsisten dibandingkan dengan perusahaan yang tingkat pertumbuhan penjualannya rendah (Hatta, 2002).

b. Market to Book Value (MTBV) atau Rasio harga Pasar terhadap nilai buku 
Market to Book Value merupakan suatu rasio yang mengindikasikan antara market value perusahaan per lembar saham dengan book value per lembar sahamnya. Nilai buku (book value) per lembar saham menunjukan aktiva bersih (net assets) yang dimiliki oleh pemegang saham (Jogiyanto, 2003).

Suatu perusahaan yang sehat dengan manajemen dan organisasi yang kuat serta berfungsi secara efisien akan memilliki nilai pasar yang lebih tinggi daripada nilai bukunya atau sama dengan nilai bukunya (Weston dan Copeland, 1999 dalam aji, 2012).

\section{Likuiditas}

Likuiditas merupakan rasio yang menggambarkan kemampuan perusahaan untuk memenuhi kewajiban jangka pendek atau utang yang segera jatuh tempo. Likuiditas perusahaan diasumsikan dapat memprediksi tingkat pengembalian investasi berupa dividen bagi investor. Likuiditas diukur dengan current ratio atau rasio lancar. Current ratio dikatakan sebagai bentuk untuk mengukur tingkat keamanan suatu perusahaan. Perhitungan current ratio dilakukan dengan cara membandingkan antara total aktiva lancar dengan total utang lancar (Kasmir, 2016:134).

\section{Kerangka Pemikiran Teoritis}

Berdasarkan landasan teori di atas, maka penelitian ini memiliki skema/kerangka pemikiran sebagai berikut:

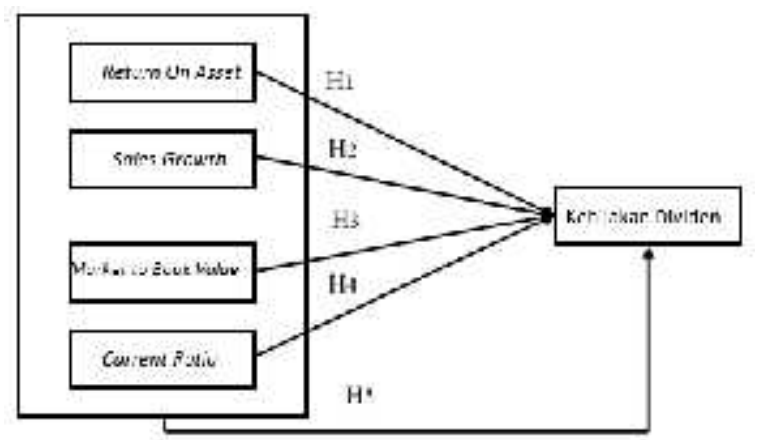

Gambar I. Kerangka Konseptual

\section{Hipotesis}

Hipotesis yang diajukan adalah :

$\mathrm{HI}$ : Return On Asset berpengaruh terhadap Dividend Payout Ratio

H2: Sales Growth berpengaruh terhadap Dividend Payout Ratio

H3: Market to Book Value berpengaruh terhadap Dividend Payout Ratio

H4: Current Ratio berpengaruh terhadap Dividend Payout Ratio

\section{METODOLOGI PENELITIAN}

Pendekatan dalam penelitian ini menggunakan penelitian kuantitatif. Menurut Sugiyono (2013), penelitian kuantitatif yaitu metode penelitian yang berlandaskan pada filsafat positivisme, digunakan untuk meneliti pada populasi atau sampel tertentu, teknik sampel pada umumnya dilakukan secara random, analisis data bersifat kuantitatif/statistik dengan tujuan untuk menguji hipotesis yang telah ditetapkan.

\section{Populasi dan Sampel}

Populasi dalam penelitian ini adalah seluruh perusahaan yang tercatat di Bursa Efek Indonesia dan melaporkan laporan keuangan tahunan (annual report) periode 2013 hingga 2016. Sampel yang digunakan dalam penelitian ini adalah perusahaan manufaktur sektor consumer goods yang terdaftar di BEI selama tahun 2013-2016dan yang masuk kriteria sampel sebanyak 12 perusahaan atau 48 firm-years.

Teknik Pengambilan Sampel dalam penelitian ini menggunakan pendekatanNon Profitability Sampling dengan metode Purposive sampling (pengambilan sampel secara disengaja) adalah teknik penentuan sampel dengan menggunakan kriteria atau pertimbangan tertentu.

\section{Metode Pengumpulan Data}

Metode pengumpulan data yang digunakan dalam penelitian ini adalah kepustakaan dan dokumentasi. Data yang digunakan adalah data sekunder yang diperoleh dari Indonesia Stock Exchange (IDX) Statistic dan Indonesian Capital Market Directoryyang dapat diakses melalui www.idx.co.id.

\section{Operasional Variabel}

Definisi dan operasionalVariabel yang digunakan dalam penelitian ini dijelaskan dalam tabel I berikut ini:

\section{Tabel I. Definisi dan Operasional Variabel}

\begin{tabular}{|l|l|}
\hline Variabel & \multicolumn{1}{|c|}{ Keterangan } \\
\hline Dividend & Definisi = Rasio antara dividen per \\
Payout & lembar saham terhadap laba \\
Ratio & perlembar saham. \\
(DPR) & Rumus = DPS/EPS \\
& Skala Pengukuran = Ratio \\
\hline
\end{tabular}




\begin{tabular}{|c|c|}
\hline $\begin{array}{l}\text { Profitabilitas } \\
\text { (ROA) }\end{array}$ & $\begin{array}{l}\text { Definisi = Rasio yang } \\
\text { memanfaatkan total assets yang } \\
\text { dimiliki oleh perusahaan untuk } \\
\text { operasi perusahaan agar } \\
\text { mendapatkan keuntungan } \\
\text { Rumus = Earning After Tax / Total } \\
\text { Assets } \\
\text { Skala Pengukuran = Ratio }\end{array}$ \\
\hline \multirow{2}{*}{$\begin{array}{l}\text { Investment } \\
\text { of } \\
\text { Opportunity } \\
\text { Set (IOS) : } \\
\text { Sales } \\
\text { Growth \& } \\
\text { Market } \\
\text { Book Value }\end{array}$} & $\begin{array}{l}\text { Definisi = Rasio antara penjualan } \\
\text { tahun berjalan dikurangi penjualan } \\
\text { tahun sebelumnya } \\
\text { Rumus =Salest }- \text { Sales } t_{\text {, }} \text { Sales } t_{\text {l }} \\
\text { Skala Pengukuran }=\text { Ratio }\end{array}$ \\
\hline & $\begin{array}{l}\text { Definisi = Rasio antara jumlah } \\
\text { saham beredar dikalikan dengan } \\
\text { harga penutupan terhadap dengan } \\
\text { total ekuitas. } \\
\text { Rumus = Market Value/Book Value } \\
\text { Skala Pengukuran = Ratio }\end{array}$ \\
\hline $\begin{array}{l}\text { Likuiditas } \\
(C R)\end{array}$ & $\begin{array}{l}\text { Definisi = Ratio antara Aktiva } \\
\text { Lancar dengan Hutang Lancar } \\
\text { Rumus = Current Assets / Current } \\
\text { Liability } \\
\text { Skala Pengukuran = Ratio }\end{array}$ \\
\hline
\end{tabular}

\section{Tehnik Analisis Data}

Metode analisis data yang digunakan terdiri dari analisis statistik deskriptif, uji asumsi klasik, analisis regresi dan uji hipotesis.

I. Uji Asumsi Klasik

2. Analisis Regresi Linier Berganda

3. Pengujian Hipotesis

\section{HASIL PENELITIAN DAN PEMBAHASAN}

\section{Hasil Penelitian}

\section{A. Uji Asumsi Klasik}

I. Uji Normalitas, hasil uji KolmogorovSimirnovnilai statistik sebesar 1,024 dengan tingkat signifikansi sebesar $0,246>0,05$ sehingga dapat disimpulkan bahwa residual menyebar normal dengan observasi sebanyak 48 data.

2. Uji Multikolonieritas, nilai VIF kurang dari 10 dannilai tolerance setiap variabel mempunyai nilai lebih dari 0, 10 dapat disimpulkan bahwa tidak ada multikolonieritas antar variabel independen dalam model regresi.

3. Uji Autokorelasi, diperoleh nilai DurbinWatson (DW) terletak antara dU dan 4-dU $(\mathrm{dU}<\mathrm{DW}<4-\mathrm{dU})=1,7206<1,862<$ 2,2794 maka dapat disimpulkan bahwa residual pada penelitian ini tidak mengandung autokorelasi baik positif maupun negatif.

4. Uji Heteroskedastisitas, dari hasil grafik Scatterplot menunjukkan data (titik-titik) menyebar secara merata di atas dan di bawah garis nol, tidak berkumpul di satu tempat, serta tidak membentuk pola tertentu, maka disimpulkan tidak terjadi heteroskedastisitas pada model regresi dalam penelitian ini.

\section{B. Analisis Regresi Linier Berganda}

Tabel 3. Hasil Uji Regresi Linier Berganda

\begin{tabular}{|l|r|r|r|r|r|}
\hline \multirow{2}{*}{ Model } & \multicolumn{2}{|c|}{$\begin{array}{c}\text { Unstandardiz } \\
\text { ed } \\
\text { Coefficients }\end{array}$} & $\begin{array}{c}\text { Standardized } \\
\text { Coefficients }\end{array}$ & \multirow{2}{*}{$\mathrm{t}$} & \multirow{2}{*}{ Sig. } \\
\cline { 2 - 5 } & $\mathrm{B}$ & $\begin{array}{c}\text { Std. } \\
\text { Error }\end{array}$ & Beta & & \\
\hline (Constant) & .250 & .134 & & 1.861 & .070 \\
ROA & 1.486 & .499 & .484 & 2.979 & .005 \\
\hline I SG & .215 & .389 & .068 & .552 & .584 \\
MTBV & .007 & .008 & .172 & .975 & .335 \\
CR & .007 & .019 & .047 & .339 & .736 \\
\hline
\end{tabular}

Dari tabel di atas dapat ditulis persamaan regresi linier sebagai berikut :

\section{DPR $=0,250+1,486$ ROA + 0.215 SG + 0.007 MTBV + 0.007 CR}

Persamaan regresi linier berganda tersebut di atas dapat diinterpretasikan sebagai berikut:

a. Nilai konstanta sebesar 0,250 menyatakan bahwa jika tidak ada pengaruh dari variabelvariabel bebas $(X 1, X 2, X 3, X 4=0)$ maka nilai DPR sebesar 0,250.

b. Nilai koefisien regresi masing-masing variabel independen (ROA, SG, MTBV dan $\mathrm{CR}$ ) menunjukkan arah pengaruh (kenaikan) terhadap DPR sebesar nilai coefisient-nya.

\section{Uji Statistik (Hipotesis)}

\section{Uji Koefisien Determinasi}

Nilai Adjusted $R$ Square pada Model Summary sebesar 0,310 . Hal ini menunjukkan bahwa $31 \%$ variabel DPR dapat dijelaskan oleh variabel Return on Asset (ROA), Sales Growth (SG), Market to Book Value (PER) dan Current Assets (CR) dan sisanya sebesar $69 \%$ dipengaruhi oleh variabel lain yang tidak dijelaskan oleh model penelitian ini.

\section{Uji Statistik t (t-test)}

a. Uji Statistik t (t-test)

Dari tabel 3, variable ROA memiliki pengaruh positif dan signifikan terhadap kebijakan dividen. Sedangkan variabel SG, MTVB dan CR memiliki pengaruh positif dan tidak signifikan terhadap kebijakan dividen.

b. Uji Statistik F (F-test)

Dari tabel 3, menunjukkan bahwa semua variabel independen ROA, SG, MTVB dan 
CR berpengaruh positif dan signifikan terhadap nilai perusahaan.

\section{Pembahasan}

\section{a. Pengaruh Profitabilitas terhadap Kebijakan dividen}

Hipotesis pertama yang diajukan menyatakan bahwa profitabilitas yang diukur oleh Return On Assets berpengaruh signifikan positif terhadap dividend payout ratio. Hasil penelitian tersebut sesuai dengan penelitian yang dilakukan oleh Marpaung (2009), Arilaha (2009), dan Musthikawati (20I0) yang menyatakan bahwa variabel ROA mempunyai pengaruh positif yang signifikan terhadap Dividend Payout Ratio.

Semakin tinggi tingkat profitabilitas yang diperoleh perusahaan, semakin besar dividen yang dibayarkan. Tanda positif dalam penelitian sesuai dengan teori signaling, MM menyatakan bahwa kenaikan dividen merupakan suatu sinyal kepada para investor bahwa manajemen meramalkan suatu penghasilan yang baik di masa yang akan datang. Hal ini membuktikan perusahaan yang memiliki kemampuan menghasilkan laba melalui aktiva yang dimiliki tercermin dalam ROA yang besar akan cenderung memberikan sinyal positif, bahwa perusahaan akan membagikan dividen yang lebih besar kepada para pemegang saham.

\section{b. Pengaruh Investment Opportunity Set \\ I) Pengaruh Sales Growth (SG) terhadap Kebijakan dividen}

Hipotesis kedua yang diajukan menyatakan bahwa Sales Growth tidak berpengaruh terhadap dividend payout ratio. Nilai signifikansi Sales Growth (SG) yaitu sebesar 0,584 lebih besar dari taraf signifikansi yaitu 0,05, maka dapat disimpulkan bahwa variabel SG secara parsial tidak berpengaruh signifikan terhadap Dividend Payout Ratio.

Hasil penelitian tersebut sesuai dengan penelitian yang dilakukan oleh Marpaung (2009), Gill, et.al (2010), Musthikawati (2010) dan Mariah, et. all (2012) yang menyatakan bahwa variabel Sales Growth tidak berpengaruh signifikan terhadap dividend payout ratio.

$\mathrm{Hal}$ ini membuktikan bahwa besar kecilnya pertumbuhan penjualan tidak akan berdampak apapun terhadap kebijakan dividen yang diberikan. Dengan tidak adanya pengaruh antara sales growth dengan dividend payout ratio maka nilai koefisien regresi pertumbuhan penjualan tidak menjelaskan apapun.
2) Pengaruh Market to Book Value (MTBV) terhadap Kebijakan dividen

Hipotesis ketiga yang diajukan menyatakan bahwa Market to Book Value berpengaruh tidak signifikan terhadap dividend payout ratio. Nilai signifikansi sebesar 0,335 lebih besar dari taraf signifikansi yaitu 0,05, maka dapat disimpulkan bahwa variabel ketiga yang diajukan menyatakan bahwa Market to Book Value tidak berpengaruh terhadap dividend payout ratio.

Hasil penelitian tersebut sesuai dengan penelitian yang dilakukan oleh Gill, et.all (2010) yang menyatakan bahwa variabel Market to Book Value tidak berpengaruh signifikan terhadap dividend payout ratio.

\section{c. Pengaruh Likuiditas (CR) terhadap Kebijakandividen}

Hipotesis keempat yang diajukan menyatakan bahwa likuiditas yang diukur dengan Current Ratio berpengaruh tidak signifikan terhadap dividend payout ratio. Hasil penelitian tersebut sesuai dengan penelitian yang dilakukan oleh Kania Bacon (2005), Arilaha (2009) dan Islamiyah (20/2) yang menyatakan bahwa variabel Current Ratio tidak berpengaruh signifikan terhadap dividend payout ratio.

Likuiditas suatu perusahaan yang diukur menggunakan variabel current ratio menunjukkan kemampuan perusahaan mendanai operasional perusahaan dan melunasi kewajiban jangka pendeknya. Hasil analisis menunjukkan bahwa tinggi rendahnya likuiditas suatu perusahaan tidak mempengaruhi besar kecilnya pembayaran dividen.

Hal ini dikarenakan likuiditas bukan digunakan membayar dividen tetapi dialokasikan pada pembelian aktiva tetap atau aktiva lancar yang permanen, guna memanfaatkan kesempatan investasi yang ada serta untuk biaya operasional. Dengan demikian perusahaan yang memiliki likuiditas yang baik tidak berarti pembayaran dividen akan lebih baik.

\section{PENUTUP}

\section{Kesimpulan}

Berdasar hasil penelitian dan pembahasan, maka dapat diambil kesimpulan sebagai berikut:

a. Terdapat pengaruh signifikan positif dari variabel ROA terhadap dividend payout ratio dengan nilai koefisien regresi ROA sebesar 0.005 , artinya setiap kenaikan ROA $1 \%$ sementara variabel independen bersifat konstan maka akan mempengaruhi kenaikan dividend payout ratio sebesar 0.005 . 
b. Tidak terdapat pengaruh signifikan dari variabel Investment Opportunity Set (IOS) yang diproksikan oleh SG dan MTBV terhadap dividend payout ratio. Dan CR terhadap dividend payout ratio. Artinya semakin tinggi atau turun SG, MTBV dan CR tidak akan mempengaruhi dividend payout ratio.

\section{Rekomendasi}

Peneliti menyadari bahwa penelitian ini masih jauh dari sempurna. Untuk itu peneliti memberikan beberapa rekomendasi sebagai berikut:

a. Bagi Praktisi, khususnya manajemen perusahaan, diharapkan dalam membuat kebijakan dividen harus mengkaji terlebih dahulu sehingga menguntungkan antara pihak perusahaan dan investor dan dapat memberikan informasi yang baik bagi investor.

b. Bagi investor, diharapkan dapat memberikan informasi tambahan mengenai perusahaan consumer goods yang terdaftar di BEl. Sehingga investor dapat berhati-hati dalam melakukan pertimbangan terhadap perusahaan yang dipilih untuk berinvestasi.

c. Bagi peneliti selanjutnya, dalam penelitian ini Nilai Adjusted $R$ Square masih kecil yaitu 0,310 maka sebaiknya sampel penelitian ditambahkan dan penelitian ini tidak hanya perusahaan dari sektor consumer goods sebagai sampel. Selain itu juga memperpanjang periode penelitian, mengingat investor lebih melihat prediksi jangka panjang dibanding prediksi jangka waktu yang relatif pendek. Sebaiknya dapat mempertimbangkan variabel seperti cash dividend, ukuran perusahaan, atau variabel lainnya.

d. Bagi Universitas, hasil penelitian ini bisa menjadi tambahan literatur dalam menambah wawasan tentang penetapan kebijakan dividen.

\section{DAFTAR PUSTAKA}

Aji, Meygawan Nurseto. 2012. Analisis Faktor-Faktor Yang Mempengaruhi Price Earning Ratio (Studi Empiris Pada Perusahaan Manufaktur Yang Terdaftar Di Bursa Efek Indonesia 2007-2010). Skripsi Tidak Dipublikasikan. Fakultas Ekonomika dan Bisnis. UNDIP, Semarang.

Arilaha, Muhammad A. 2009. "Pengaruh Free Cash Flow, Profitabilitas, Likuiditas, dan Leverage Terhadap Kebijakan
Dividen". Jurnal Keuangan dan Perbankan. Vol. 13, No. I.

Bhattacharya, S. (1979). Imperfect Information, Dividend Policy and the Bird in the Hand Fallacy Bell. Journal of Economics.

Dadri, Putu Terestiani. 20II. Pengaruh Investment Opportunity Set Dan Struktur Modal Terhadap Return Saham Pada Perusahaan Farmasi Di Bursa Efek Indonesia. Program Pascasarjana Universitas Udayana, Denpasar.

Damayanti, Susana dan Fatchan Achyani. 2006. Analisis Pengaruh Investasi, Likuiditas, Profitabilitas, Pertumbuhan perusahaan dan Ukuran Perusahaan terhadap Dividend Payout Ratio (Studi Empiris pada perusahaan Manufaktur yang Terdaftar di Bursa Efek Jakarta). Jurnal Akuntansi dan Keuangan, Vol. 5, No. I April 2006.

Darminto. 2008. Pengaruh Profitabilitas, Likuiditas, Struktur Modal Dan Struktur Kepemilikan Saham Terhadap Kebijakan Dividen. Jurnal Ilmu-Ilmu Sosial (Social Sciences). Vol 20 No 2.

Deitiana, Tita. 20II. Pengaruh Rasio Keuangan Pertumbuhan Penjualan Dan Dividen Terhadap Harga Saham. Jurnal Bisnis Dan Akuntansi. Vol.I3, No.I.

Dewi, S.C., (2008). Pengaruh Kepemilikan Manajerial, Kepemilikan Institusional, Kebijakan Utang, Profitabilitas, dan Ukuran Perusahaan Terhadap Kebijakan Dividen. Jurnal Bisnis dan Akuntansi, Volume 10 No I.

Embara, Cecilia Triana Dewi Lestari, et. all. 2012. Variabel-Variabel Yang Berpengaruh Terhadap Kebijakan Dividen Serta Harga Saham Pada Perusahaan Manufaktur Di Bursa Efek Indonesia. Jurnal Manajemen, Strategi Bisnis, dan Kewirausahaan Vol. 6, No. 2.

Ghozali, Imam. 2012. Aplikasi Analisis Multivariate Dengan Program IBM SPSS 20. Edisi ke 6. Semarang

Gill, Amarjit, Nahum Biger and Rajendra Tibrewala. 2010. Determinants Of Dividend Payout Ratio: Evidence From United States. The Open Business Journal. Vol 3.

Hardiatmo, Budi. 2012. Analisis FaktorFaktor Yang Mempengaruhi Kebijakan Dividen (Studi Empiris Perusahaan Manufaktur Yang Di Listing Di Bursa 
Efek Indonesia Periode 2008-2010). Skripsi Tidak Dipublikasikan. Fakultas Ekonomika dan Bisnis . UNDIP, Semarang.

Hatta, Atika J. 2002. Faktor-faktor yang Mempengaruhi Kebijakan Dividen: Investifasi Pengaruh Teori Stakeholder. JAAI. Vol.6. No.2. Desember. Jogiyanto. 2000. Teori Portofolio dan Analisis Investasi. Edisi ke 3. Yogyakarta. Kasmir. 2016. Analisa Laporan Keuangan. Jakarta. Rajawali Pers

Laksono, Bagus. 2006. Analisis pengaruh Return On Asset, Sales Growth, Asset Growth, Cash Flow dan Likuiditas Terhadap Dividend Payout Ratio. Program Pasca Sarjana. UNDIP. Semarang .

Latiefasari, Hani Diana. 20II. Analisis Faktor-

Faktor Yang Mempengaruhi Kebijakan Deviden (Studi Empiris Pada Perusahaan Manufaktur Yang Terdaftar Di Bei Periode 2005-2009). Skripsi Tidak Dipublikasikan. Fakultas Ekonomi. UNDIP, Semarang.

Mariah, Meythi, dan Riki Martusa. 2012. Pengaruh Profitabilitas Dan Kesempatan Investasi Terhadap Kebijakan Dividen Tunai Dengan Likuiditas Sebagai Variabel Moderating Pada Emiten Pembentuk Indeks LQ 45 (Perioda 2008-2010). Seminar Nasional Akuntansi Dan Bisnis (SNAB).

Marpaung, E.I dan Hadianto Bram (2009). Pengaruh Profitabilitas Dan Kesempatan Investasi Terhadap Kebijakan Dividen: StudiEmpirik Pada Emiten Pembentuk Indeks LQ45 Di Bursa Efek Indonesia. Jurnal Akuntansi. Volume I No.I.

Michell Suharli, 2006, "Studi Empiris Mengenai Pengaruh Profitabilitas, Leverage, dan Harga Saham Terhadap Jumlah Dividen Tunai (Studi pada Perusahaan yang Terdaftar di Bursa Efek Jakarta Periode 2002-2003)", Jurnal Maksi, Vol. 6, No. 2

Musthikawati, Noventri. 2010. Faktor-Faktor Yang Mempengaruhi Rasio Pembayaran Dividen. Skripsi Dipublikasikan. Fakultas Ekonomi. Universitas Sebelas Maret, Surakarta.

Nugraha, Dimas Adi. 2012. Analisis Pengaruh Insider Ownership, Debt To Equity Ratio, Return On Equity, Firm Size Dan Investment Of Opportunity Set Terhadap Dividend Payout Ratio (Studi Kasus Pada Perusahaan
Manufaktur Yang Terdaftar Di Bursa Efek Indonesia Tahun 2007-2010). Skripsi Tidak dipublikasikan. Fakultas Ekonomi. UNDIP.

Nugroho, Andharu Haryo. 20II. Faktorfaktor yang Mempengaruhi Dividend Payout Ratio (Studi Empiris pada Perusahaan yang Terdaftar dalam Bursa Efek Indonesia). Skripsi Tidak dipublikasikan. Fakultas Ekonomi. UNDIP.

Sadalia, I dan Saragih (2008). Pengaruh Profitabilitas Dan Investment Opportunity Set Terhadap Dividen Tunai Pada Perushaan Terbuka Di Bursa Efek Indonesia Jurnal manajemen bisnis. Volume 3.

Sugiarso dan Winarni (2005). Pemahaman Laporan Keuangan, Pengelolaan Aktiva, Kewajiban, dan Modal, serta Pengukuran Kinerja Perusahaan. Yogyakarta.

Sugiyono. 2010. Metode Penelitian Bisnis (Penelitian Kuantitatif, Kualitatif dan R\&D). Bandung Alfabeta

Suharli, Michell. 2007. Pengaruh Profitability dan Investment Opportunity Set Terhadap Kebijakan Dividen Tunai dengan Likuiditas Sebagai Variabel Penguat. Jurnal Akuntansi dan Keuangan. Vol.9, No.l.

Tjandra Ronowati. 2005. Pengaruh Investment Opportunity Set (IOS) Terhadap Kebijakan Dividen Dengan Pemoderasi Pilihan Prosedur Akuntansi Pada Perusahaan yang Go Public Di BEJ. Jurnal Bisnis \& Manajemen. (Volume 5).

Probosari, Galuh Kusumo. 20II. Analisis Pengaruh Npm, Quick Ratio, Der, Sales Growth Dan Size Terhadap Dividend Payout Ratio Pada Perusahaan Non-Finansial Yang Terdaftar Di Bursa Efek Indonesia Periode Tahun 2005-2009. Skripsi UNDIP, Semarang.

Weston dan Copeland, 1995, Manajemen

Keuangan, Bina Rupa Aksara, Jakarta http://www.mappijatim.or.id/ragam-berita/beisiapkan-regulasi-emiten-tak-bagi-dividen.html www.idx.co.id 